\title{
ARTYKULY
}

Forum Pedagogiczne

$2014 / 1$

\author{
ANDRZEJ TWARDOWSKI \\ Uniwersytet im. Adama Mickiewicza \\ Poznań (Polska)
}

\section{NOWA KONCEPCJA WCZESNEGO WSPOMAGANIA ROZWOJU DZIECI Z NIEPEŁNOSPRAWNOŚCIAMI}

Streszczenie: Przedmiotem artykułu jest nowa koncepcja wczesnego wspomagania rozwoju dzieci z niepełnosprawnościami. Dopiero w ostatnim dwudziestoleciu tradycyjny paradygmat wczesnego wspomagania, skoncentrowany na specjalistach, został zastąpiony nowym, skoncentrowanym na rodzinie. Istota zmiany polegała na odejściu od oddziaływań prowadzonych bezpośrednio z niepełnosprawnym dzieckiem na rzecz współpracy z rodziną i budowania partnerskich relacji z jej członkami.

Autor przedstawia własny model wczesnego wspomagania rozwoju dziecka skoncentrowanego na interakcjach rodzice - dziecko. Opisuje cztery główne elementy modelu: (1) cechy interakcji wspomagających rozwój dziecka, (2) codzienne czynności rodziny, (3) ciekawość i zainteresowania dziecka oraz (4) strategie postępowania rodziców w toku interakcji z dzieckiem.

Słowa kluczowe: wczesne wspomaganie, dzieci z niepełnosprawnościami, rozwój, rodzina.

\section{Wprowadzenie}

Rozwój małego dziecka, także dziecka z niepełnosprawnością, dokonuje się przede wszystkim w kontekście środowiska rodzinnego, w toku interakcji z osobami najbliższymi. Carl Dunst wykazał, że dwie godziny specjalistycznych oddziaływań tygodniowo zajmuje w pierwszym roku życia zaledwie $2 \%$ czasu aktywności dziecka. Pozostałe $98 \%$ czasu niemowlę spędza w kontakcie z rodzicami i innymi członkami rodziny ${ }^{1}$. W okresie przedszkolnym dzieci objęte programami wczesnego wspomagania rozwoju spędzają w kontakcie ze specjalistami 7,9\% ogółu czasu, a pozostałe $92,1 \%-z$ osobami najbliższymi².

${ }^{1}$ C. Dunst, Early intervention for infants and toddlers with developmental disabilities, [w:] Handbook of developmental disabilities, red. S. Odom, R. Horner, M. Snell, J. Blacher, Guilford Press, New York 2007, s. 161-180.

${ }^{2}$ G. Mahoney, J. MacDonald, Autism and developmental delays in young children. The responsive teaching curriculum for parents and professionals, PRO-ED, Austin 2007, s. 11. 
Przedstawione liczby dowodzą, że rodzice, a także inni członkowie rodziny mają największy wpływ na rozwój małego dziecka z niepełnosprawnością i dlatego ich udział w procesie wczesnego wspomagania jest niezbędny. Nasuwają też pytania: jaki jest główny cel wczesnego wspomagania rozwoju dzieci z niepełnosprawnościami?, jaki model wspomagania jest najbardziej właściwy?, jak zorganizować proces wspomagania?, jak włączyć w niego rodziców? Treść artykułu stanowi próbę udzielenia odpowiedzi na wymienione pytania.

\section{Paradygmat wczesnego wspomagania rozwoju dziecka skoncentrowanego na rodzinie}

Do lat dziewięćdziesiątych XX wieku w programach pomocy udzielanej rodzinom wychowującym małe dzieci z niepełnosprawnościami dominował paradygmat medyczny. Uważano, że rodzice nie potrafią poradzić sobie z sytuacją, w jakiej się znaleźli ani określić, jakiej pomocy potrzebują. Dlatego wsparcie udzielane rodzinie pozostawało pod pełną kontrolą specjalistów i było zorientowane na bezpośrednią pracę z dzieckiem. Specjaliści koncentrowali się na pomaganiu niepełnosprawnemu dziecku w oderwaniu od interakcji rodzice - dziecko oraz bez uwzględniania problemów rodziny jako całości. Większość zajęć z dzieckiem odbywała się w specjalistycznych gabinetach. Rodzice występowali w roli pomocników i wykonawców poleceń specjalistów. Czasami przeprowadzali określone oddziaływania terapeutyczne, ściśle według dostarczonych instrukcji.

Skuteczność medycznego paradygmatu wspomagania rodzin wychowujących małe dzieci z niepełnosprawnościami była niska z co najmniej kilku powodów. Po pierwsze, specjaliści skupiali się na usprawnianiu dziecka, zaniedbując współpracę z rodzicami i innymi członkami rodziny. Po drugie, pomoc była skoncentrowana głównie na rehabilitacji fizycznej i usprawnianiu mowy dziecka, kosztem pobudzania jego funkcjonowania poznawczego i społeczno-emocjonalnego. Po trzecie, rodzice musieli kontaktować się z wieloma specjalistami, co powodowało, że uzyskiwali informacje niejasne, niespójne, a niekiedy sprzeczne. Po czwarte, nie sprawdziły się programy, w których pomoc traktowana była jako zestaw specjalistycznych usług, z których każda dotyczyła innej dysfunkcji występującej u dziecka. Po piąte, stwierdzono, że programy pomocy, w których rodziców uczono, jak mają wykonywać różne ćwiczenia, są mało skuteczne, ponieważ rodzice, po napotkaniu na trudności, szybko się zniechęcali. Wymienione niedostatki spowodowały, że w ostatnim dwudziestoleciu medyczny paradygmat wspomagania skoncentrowany na specjalistach stopniowo ustąpił miejsca nowemu, skoncentrowanemu na rodzinie. Istotą nowego paradygmatu jest odejście od bezpośrednich oddziaływań na dziecko na rzecz oddziaływania na rodziców i opiekunów, a mówiąc ściślej - na rzecz oddziaływania 
na dziecko za pośrednictwem rodziców i opiekunów ${ }^{3}$. Paradygmat pomocy skoncentrowanej na rodzinie opiera się na siedmiu założeniach.

Po pierwsze, udzielana pomoc służy upełnomocnieniu rodziców ${ }^{4}$. Zadaniem specjalistów jest nie tylko wykształcenie u rodziców i innych członków rodziny umiejętności niezbędnych w wychowaniu niepełnosprawnego dziecka, ale przede wszystkim ukształtowanie u nich takich kompetencji, jak: (1) zaangażowanie, (2) poczucie skuteczności (self-efficacy), (3) umiejętność zaspokajania własnych potrzeb, (4) umiejętność korzystania z dostępnych zasobów, (5) rozumienie otoczenia społecznego i wiara w możliwość wywierania wpływu na nie, (6) przekonanie, że to, co się robi, jest wartościowe oraz (7) poczucie możliwości decydowania o sobie (self-determination $)^{5}$.

Po drugie, kontekstem wspomagania rozwoju dziecka są sytuacje życia rodzinnego. Wśród bliskich osób i znanych przedmiotów dziecko czuje się bezpiecznie. $\mathrm{Z}$ własnej woli podejmuje różne czynności. Natomiast w specjalistycznym gabinecie o rodzaju i sposobie wykonywania czynności decyduje terapeuta. Dlatego najlepsze efekty przynoszą działania wplecione w rytm codziennych, rutynowych czynności, wykonywane $\mathrm{w}$ toku naturalnych interakcji z rodzicami i innymi domownikami ${ }^{6}$.

Po trzecie, rodzice i specjaliści pozostają w symetrycznej relacji. Oznacza to, że żadna ze stron nie dominuje nad drugą - nie narzuca jej swojej woli, nie obciąża nadmiarem obowiązków, nie obarcza odpowiedzialnością za poniesione porażki. Również żadna ze stron nie przypisuje sobie wyłącznych zasług za osiągnięte sukcesy.

Po czwarte, specjaliści zachęcają rodziców do dokonywania wyborów i podejmowania decyzji. Traktują rodziców jako rzeczywistych ekspertów w sprawach dziecka. Nie narzucają im żadnych rozstrzygnięć. Koncentrują się na dostarczaniu wyczerpujących informacji o programach pomocy oraz wskazują na korzyści, jakie mogą przynieść dziecku i całej rodzinie. Zachęcają rodziców, aby samodzielnie podejmowali decyzje odnośnie potrzebnej im pomocy?

Po piąte, pomoc dla rodziny jest zindywidualizowana i elastyczna. Każda rodzina i każde niepełnosprawne dziecko mają specyficzne, niepowtarzalne właściwości.

${ }^{3}$ A. Twardowski, Wczesne wspomaganie rozwoju dzieci z niepetnosprawnościami w środowisku rodzinnym, Wydawnictwo Naukowe UAM, Poznań 2012, s. 10.

4 Termin upełnomocnienie (ang. empoverment) pochodzi od łacińskiego słowa potere, które oznacza „móc”, „,być w stanie”, ,potrafić”. Czasami jest tłumaczony jako: „,upodmiotowienie”, „wzmocnienie”, „umocnienienie” lub „usamodzielnienie”. Idea upełnomocnienia pojawiła się w USA w latach 60. XX wieku i rozwinęła w następnej dekadzie wraz z rozwojem ruchów społecznych zmierzających do ograniczenia ubóstwa, wyeliminowania dyskryminacji, zmniejszenia nierówności w dostępie do opieki zdrowotnej oraz obudzenia świadomości politycznej obywateli.

5 M. Zimmerman, Psychological empowerment: Issues and illustrations, „American Journal of Community Psychology" 23(1995)5, s. 581-599.

${ }^{6}$ M. Dąbrowska, Wczesne wspomaganie. Wsparcie psychologiczno-pedagogiczne, Fundacja Rozwoju Regionalnego, Kraków 2009, s. 18.

7 M. Bruder, Early childhood intervention: A promise to children and families to their future, „Exceptional Children” 76(2010)3, s. 339-415. 
Dlatego przed rozpoczęciem oddziaływań należy poznać sposób funkcjonowania rodziny, a także zidentyfikować potrzeby i preferencje poszczególnych członków rodziny oraz rodziny jako całości. Programy pomocy powinny być dostosowane do specyfiki funkcjonowania danej rodziny ${ }^{8}$. Powinny uwzględniać panujące w rodzinie zwyczaje i obyczaje oraz preferowane przez nią wartości.

Po szóste, oddziaływania pomocowe należy oprzeć na mocnych stronach rodziny i jej planach na przyszłość. Zasoby i kompetencje dziecka, rodziców i innych członków rodziny powinny stanowić punkt wyjścia przy opracowywaniu programu oddziaływań pomocowych. Ponadto należy ustalić, jaką wizję przyszłości posiada rodzina i czy jest ona realistyczna, czyli możliwa do osiągnięcia9.

Po siódme, w relacjach z rodzicami specjaliści stosują partnerski styl porozumiewania się. Otwarte i szczere porozumiewanie się jest warunkiem skutecznej pomocy. Rodzice najlepiej znają swoje dziecko. Potrafią wskazać przyczyny jego nietypowych zachowań, wyjaśnić znaczenie niezrozumiałych wypowiedzi, opisać ulubione czynności. Dlatego specjaliści najpierw powinni wysłuchać rodziców, a dopiero później pytać, dyskutować i udzielać porad ${ }^{10}$.

Przedstawione założenia wskazują, że w paradygmacie pomocy skoncentrowanej na rodzinie kładzie się szczególny nacisk na współpracę z rodzicami i innymi członkami rodziny. Specjaliści występują w roli partnerów i pomocników rodziny. Uważają, że rodzina jest zdolna do podejmowania samodzielnych decyzji i zgodnego z nimi postępowania. Wspierają rodzinę w taki sposób, aby jej funkcjonowanie ulegało stałej poprawie i dzięki temu zapewniało niepełnosprawnemu dziecku optymalny rozwój.

\section{Definicja wczesnego wspomagania rozwoju dziecka}

W dotychczasowej praktyce wczesnego wspomagania rozwoju dziecka zbyt duże znaczenie przywiązywano do interakcji specjaliści - dziecko, natomiast nie doceniano roli interakcji między dzieckiem a rodzicami i innymi domownikami. Dopiero w ciągu ostatniego dwudziestolecia nastąpił odwrót od paradygmatu medycznego skupionego tylko na niepełnosprawnym dziecku. Pojawiło się nowe podejście, w którym przy projektowaniu oddziaływań pomocowych bierze się pod uwagę zarówno dziecko, jak i jego rodziców oraz innych członków rodziny. Innymi słowy, w nowym paradygmacie odbiorcą specjalistycznej pomocy jest nie tylko dziecko, ale cała rodzina. W związku z tym istotne są zarówno interakcje specjalistów z dziec-

${ }^{8}$ S. McBridge, C. Peterson, Home-based early intervention with families of children with disabilities: Who is doing what?, „Topics in Early Childhood Special Education” 17(1997)2, s. 209-233.

9 T. Moore, H. Larkin, "More than my child's disability..." A comprehensive review of family-centered practices and family experiences of early childhood intervention service, Scope, Melbourne 2006.

${ }_{10} \mathrm{R}$. McWilliam, Routine-based early intervention: supporting young children and their families, Brookes Publishing, Baltimore 2010. 
kiem i jego rodzicami, jak i interakcje dziecka z rodzicami i innymi członkami rodziny. Zatem zasadniczym celem wczesnego wspomagania rozwoju dziecka powinno być doskonalenie interakcji między opiekunami a dzieckiem, ponieważ one stanowią kontekst rozwoju dziecka i decydują o jego jakości.

$\mathrm{W}$ moim rozumieniu „wczesne wspomaganie rozwoju jest procesem planowych i systematycznych oddziaływań mających na celu ukształtowanie takich wzorców interakcji między opiekunami a dzieckiem, które najbardziej sprzyjają usprawnianiu jego funkcjonowania fizycznego, psychicznego i społecznego. Oddziaływania prowadzone są przez zespół specjalistów w ścisłej współpracy z rodziną i obejmują dzieci zagrożone niepełnosprawnością oraz niepełnosprawne od chwili wykrycia zagrożenia lub stwierdzenia niepełnosprawności do podjęcia nauki w szkole"11.

Przyjęta definicja wskazuje na cztery grupy adresatów wczesnego wspomagania rozwoju. Do pierwszej należą dzieci, które urodziły się z niepełnosprawnościami, na przykład z wrodzonymi wadami narządów zmysłów, wadami genetycznymi, uszkodzeniami ośrodkowego układu nerwowego. Niepełnosprawność stwierdza się bezpośrednio po urodzeniu lub w pierwszych dniach życia dziecka. Drugą grupę stanowią dzieci, które przyszły na świat zdrowe i rozwijały prawidłowo, ale ich rozwój uległ zaburzeniu z powodu urazu, choroby lub zadziałania szkodliwego czynnika - na przykład utraciły wzrok lub sprawność ruchową na skutek nieszczęśliwego wypadku, doznały uszkodzenia mózgu w wyniku zatrucia lub niedotlenienia, zapadły na przewlekłą chorobę. Do grupy trzeciej zalicza się dzieci zagrożone niepełnosprawnością z powodu opóźnień lub zaburzeń rozwoju w jednej lub kilku sferach. Jeśli nieprawidłowości występują w kilku sferach lub większości z nich, wówczas mówi się o „opóźnionym rozwoju psychoruchowym” lub „wolniejszym rozwoju” ${ }^{2}$. Do czwartej grupy należą dzieci zagrożone niepełnosprawnością z powodu nieprawidłowego przebiegu ciąży, niskiej wagi urodzeniowej, komplikacji porodowych lub niekorzystnych warunków środowiskowych. Są to tzw. „dzieci ryzyka”. I chociaż u dzieci z grupy trzeciej i czwartej nie stwierdza się niepełnosprawności, to prawdopodobieństwo jej wystąpienia jest wysokie. Dlatego dzieci z obu grup należy objąć oddziaływaniami wspomagającymi rozwój.

Warunkiem skuteczności wczesnego wspomagania rozwoju jest współpraca między specjalistami oraz ścisła współpraca specjalistów z rodziną. Należy mocno podkreślić, że nie chodzi wyłącznie o współpracę z rodzicami czy prawnymi opiekunami dziecka, ale także z pozostałymi członkami rodziny, którzy na co dzień przebywają $\mathrm{z}$ niepełnosprawnym dzieckiem ${ }^{13}$. Udział rodziny jest niezbędny na każdym etapie

${ }^{11}$ A. Twardowski, Wczesne wspomaganie rozwoju dzieci, dz. cyt., s. 131.

${ }^{12}$ E. Gruszczyk-Kolczyńska, E. Zielińska, Wspomaganie rozwoju umystowego trzylatków i dzieci starszych wolniej rozwijajacych sie, WSiP, Warszawa 2000.

${ }^{13} \mathrm{~S}$. Wrona, Wczesna interwencja $i$ wczesne wspomaganie procesem wspierajacym rozwój małego dziecka, [w:] Wsparcie instytucjonalne osób niepetnosprawnych w Polsce i Republice Czeskiej, red. I. Fajfer-Kruczek, S. Wrona, Wyd. „ARKA”, Cieszyn 2010. 
wczesnego wspomagania rozwoju dziecka: diagnozy, tworzenia planu pomocy i jego realizacji. W procesie wspomagania należy odejść od koncentracji na deficytach dziecka na rzecz zapewnienia mu kompleksowej pomocy w środowisku rodzinnym.

Zgodnie $\mathrm{z}$ przedstawioną definicją wczesne wspomaganie rozwoju jest skoncentrowane na pracy $\mathrm{z}$ rodziną dziecka niepełnosprawnego lub zagrożonego niepełnosprawnością, a nie na samym dziecku. Nie neguję zasadności prowadzenia specjalistycznych oddziaływań bezpośrednio z dzieckiem. Często są one niezbędne, na przykład z powodu specyfiki zaburzenia, przeżywanego przez rodzinę kryzysu emocjonalnego lub niewydolności wychowawczej rodziny. Natomiast uważam, że wczesne wspomaganie rozwoju przynosi najlepsze efekty, gdy prowadzone jest podczas codziennych, rutynowych czynności, w kontekście naturalnych interakcji między opiekunami a dzieckiem. Dlatego specjaliści powinni dążyć do ukształtowania takich wzorców interakcji opiekunowie - dziecko, które umożliwiają dziecku gromadzenie doświadczeń najbardziej korzystnych dla rozwoju. Najbardziej optymalne są interakcje, w trakcie których opiekunowie wspierają dziecko w jego wysiłkach związanych z uczeniem się.

\section{Charakterystyka modelu wczesnego wspomagania rozwoju skoncentrowanego na interakcjach rodzice - dziecko ${ }^{14}$}

Od pierwszych tygodni życia dziecko jest aktywnym partnerem interakcji. Przychodzi na świat wyposażone w zachowania, które mają charakter społeczny, ponieważ służą utrzymywaniu bliskości z ludźmi ${ }^{15}$. Jest zdolne do inicjowania kontaktów i reagowania na zachowania opiekuna. W niemowlęctwie dziecko rozwija się dzięki interakcjom z głównym opiekunem, którym zazwyczaj jest matka, a w późniejszych latach również poprzez interakcje z innymi bliskimi mu osobami. Zatem oddziaływania wspomagające rozwój nie powinny być skierowane wyłącznie na dziecko, ale obejmować interakcje opiekunowie - dziecko.

\subsection{Cechy interakcji wspomagającej rozwój}

Dla celów dalszych rozważań przyjmuję, że termin „interakcja” oznacza wymianę zachowań społecznie ukierunkowanych między dwoma osobami pozostającymi w bezpośrednim kontakcie ${ }^{16}$. Wymianę tę cechuje: następstwo czasowe, przestrzeganie kolejności reagowania, wspólne dla obu partnerów pole uwagi oraz wspólny

${ }^{14}$ Szczegółową charakterystykę modelu wczesnego wspomagania rozwoju skoncentrowanego na interakcjach rodzice - dziecko z niepełnosprawnością zamieściłem w książce pt. Wczesne wspomaganie rozwoju dzieci, dz. cyt., s. 212-283. W niniejszym opracowaniu ograniczam się do przedstawienia najważniejszych elementów tego modelu.

${ }_{15}$ J. Bowlby, Przywiazanie, Wyd. Nauk. PWN, Warszawa 2007.

${ }_{16}$ B. Bokus, Nawiazywanie interakcji społecznych przez mate dziecko, Ossolineum, Wrocław 1984. 
temat. Aby mówić o interakcji konieczne są co najmniej dwa zachowania społecznie ukierunkowane, pochodzące kolejno od każdego z partnerów. Zachowanie społecznie ukierunkowane to spojrzenie, działanie lub wypowiedź kierowane przez daną osobę do drugiej i potencjalnie przez drugą osobę spostrzegane.

W celu określenia cech interakcji wspomagającej rozwój dziecka wykorzystałem dwa źródła danych. Pierwszym była teoria przywiązania, a szczególnie wyniki longitudinalnych badań bostońskich Mary Ainsworth i współpracowników, zawierające opisy interakcji matka - dziecko oraz charakterystyki Skal Wrażliwości Macierzyńskiej ${ }^{17}$. Drugim źródłem danych były wyniki badań nad rozwojem dziecka we wczesnej ontogenezie, zrealizowanych $\mathrm{w}$ ramach paradygmatu społeczno-interakcyjnego $^{18}$. Wyodrębniłem sześć cech interakcji opiekun - dziecko, najbardziej korzystnych dla rozwoju dziecka.

Pierwszą cechą interakcji wspomagającej rozwój jest okazywanie dziecku miłości. Rodzice posługują się wieloma zachowaniami, aby okazać pozytywne uczucia i zaangażować dziecko w wymianę interpersonalną. Są to między innymi: dotykanie, przytulanie, całowanie, kołysanie, pieszczenie, uśmiechanie się, czułe spoglądanie, wokalizowanie, wchodzenie w kontakty „twarzą w twarz” o żartobliwym charakterze. W odpowiedzi dziecko reaguje radosnym ożywieniem, odwzajemnia uśmiechy, wokalizacje i spojrzenia. Stopniowo coraz częściej i chętniej inicjuje interakcje, posługując się bogatym repertuarem reakcji przywiązania ${ }^{19}$.

Drugą cechą interakcji wspomagającej rozwój jest wrażliwe odpowiadanie na zachowania dziecka. Jeśli rodzice chcą wywrzeć jakikolwiek wpływ na dziecko, muszą być wysoce wrażliwi na sygnały płynące z jego strony. Muszą dostrzegać potrzeby, zainteresowania i umiejętności ujawniane przez dziecko, aby ocenić jakiego rodzaju wsparcia w danym momencie potrzebuje. Stwierdzono, że już w pierwszych tygodniach życia dziecka matka obdarza je czujną uwagą - często podchodzi, spogląda, przysłuchuje się, dotyka, bierze na ręce. W zależności od aktualnego stanu dziecka odpowiada natychmiast i odpowiednio. Na przykład, podrzuca dziecko na kolanach, huśta w powietrzu i rozśmiesza, aby je pobudzić lub przytula, kołysze i daje smoczek, aby je uspokoić ${ }^{20}$.

Podzielanie tematu to trzecia cecha interakcji wspomagającej rozwój dziecka. Każda interakcja społeczna ma określony temat. Jest nim przedmiot, zdarzenie lub inna cecha otoczenia, które skupiają wspólne zaangażowanie partnerów ${ }^{21}$. Jeżeli działania partnerów koncentrują się wokół wspólnego elementu, wówczas nadaje on

${ }_{17}$ M. Ainsworth, M. Blehar, E. Waters, S. Wall, Patterns of attachment: A psychological study of the strange situation, Erlbaum, Hillsdale 1978.

18 A. Brzezińska, Społeczna psychologia rozwoju, Wyd. Nauk. „Scholar”, Warszawa 2000.

${ }^{19}$ H. Schaffer, Poczatki uspołecznienia dziecka, PWN, Warszawa 1981.

${ }^{20}$ Tamże, s. 184.

${ }^{21}$ H. Schaffer, Epizody wspólnego zaangażowania jako kontekst rozwoju poznawczego, [w:] Dziecko w świecie ludzi i przedmiotów, red. A. Brzezińska, G. Lutomski, Wyd. Zysk i S-ka, Poznań 1994, s. 153. 
kierunek interakcji i wyznacza jej treść. W miarę rozwoju dziecka tematy coraz częściej przybierają formę werbalną, a interakcje stają się konwersacjami.

Wspólny temat jest niezbędny, aby rodzic mógł dziecko czegoś nauczyć. Uczenie dziecka wymaga posługiwania się różnymi strategiami. Mogą one mieć charakter niewerbalny (np. demonstrowanie, wskazywanie) lub werbalny (np. nazywanie, zadawanie pytań). Strategie te ,polegają na stymulowaniu i pobudzaniu dziecka względem świata znajdującego się poza parą, na ukierunkowywaniu jego uwagi na własności, przedmioty lub wydarzenia w otoczeniu, na wprowadzaniu, upośrednianiu i interpretowaniu świata zewnętrznego oraz na wywoływaniu lub dostarczaniu okazji, aby obserwować, naśladować, mówić i uczyć się"22.

Czwartą cechą interakcji wspomagającej rozwój jest dopasowanie oddziaływań do potrzeb i możliwości dziecka. Stwierdzono, że matki starają się oddziaływać na niemowlę w taki sposób, aby jego pobudzenie pozostawało na optymalnym poziomie. Kiedy wchodzą z dzieckiem w interakcje czynią to łagodnie, zaś podczas interakcji nie przeciążają dziecka i nie wywołują u niego nadmiernej ekscytacji. Potrafią zauważyć i trafnie zinterpretować pierwsze sygnały nadmiernego napięcia lub zmęczenia. Wówczas, aby nie doprowadzić do przestymulowania dziecka, zmniejszają tempo i intensywność oddziaływań. $Z$ drugiej strony dbają, aby nie dochodziło do sytuacji, w których dziecko uzyskuje zbyt mało stymulacji. Na przykład szybko i adekwatnie reagują, kiedy dziecko sygnalizuje, że jest znudzone i chciałoby podjąć interakcję.

Mary Ainsworth wykryła jeszcze jedną, interesującą prawidłowość dotyczącą dostosowywania się matek do zachowań dziecka. Pod koniec wieku niemowlęcego, a następnie $\mathrm{w}$ okresie poniemowlęcym matki starają się odpowiadać na sygnały i komunikaty dziecka w taki sposób, aby nie tylko zaspokoić jego aktualne potrzeby, ale także zapewnić mu wyższy poziom kompetencji w przyszłości ${ }^{23}$. Używając terminologii Lwa Wygotskiego można powiedzieć, że matki zaczynają działać w strefie najbliższego rozwoju dziecka.

Kolejną, piątą cechą interakcji wspomagającej rozwój dziecka jest wzajemność. Interakcja musi być podtrzymywana przez działanie obu partnerów, a ich role powinny się dopełniać i być wymienne. Inaczej mówiąc, interakcja jest wzajemna, gdy partnerzy koordynują swe zachowania, wspólnie za nią odpowiadają i każdy ma udział $w$ jej przebiegu.

Tradycyjny pogląd, że tylko rodzic określa tempo i charakter interakcji jest nieaktualny. Od samego początku rodzic i dziecko wpływają na siebie nawzajem. Dzieje

${ }^{22}$ M. Bornstein, Pomiędzy opiekunami a ich potomstwem: dwa rodzaje interakcji i ich konsekwencje dla rozwoju poznawczego, [w:] Dziecko wśród rówieśników i dorostych, red. A. Brzezińska, G. Lutomski, B. Smykowski, Wyd. Zysk i S-ka, Poznań 1995, s. 43.

${ }^{23}$ M. Ainsworth, Attachments across the life span, „Bulletin of the New York Academy of Medicine" 61(1985)9, s. 771-791. 
się to w trakcie codziennych, bezpośrednich kontaktów takich, jak czynności pielęgnacyjne i zabawy. „Niemowlęta przynajmniej tak często jak matki inicjują sekwencje zachowań za pomocą takich środków, jak wokalizacja, dotyk i spojrzenie, na które matki odpowiadają w sposób uznawany przez nie za właściwy w kontekście obecnego stanu i zainteresowania niemowlęcia"24.

Kierowanie zachowaniem dziecka to szósta cecha interakcji wspomagającej rozwój. Najbardziej korzystną formą kierowania zachowaniem dziecka jest współpraca z nim. Matka nie przerywa czynności wykonywanej przez dziecko, ale czeka aż ją zakończy i dopiero wtedy proponuje kolejne działanie. W żartobliwy sposób stara się zachęcić dziecko do zamiany dotychczasowego zachowania na takie, które uznaje za bardziej właściwe. Używa technik regulujących stan emocjonalny dziecka. Na przykład, aby uspokoić dziecko przed snem stopniowo redukuje tempo i natężenie interakcji. Zamiast używać nakazów i zakazów stara się zainteresować dziecko czynnościami wykonywanymi we współpracy. Tak aranżuje środowisko fizyczne w domu, aby zminimalizować bezpośrednią kontrolę nad dzieckiem i konieczność ingerowania w jego czynności. Takie postępowanie świadczy, że matka traktuje dziecko w sposób podmiotowy - jako osobę, której potrzeby i czynności są „wartością samą w sobie" 25 .

\subsection{Codzienne czynności rodziny}

W proponowanym modelu codzienne czynności rodziny są traktowane jako kontekst wczesnego wspomagania rozwoju dziecka. Stanowią one źródło naturalnych, spontanicznych okazji do uczenia się różnorodnych umiejętności. To, w jakim zakresie owe okazje zachęcą dziecko do uczenia się, zależy od ich charakteru, tzn. od tego kto, kiedy, gdzie i co czyni. Czynności rodziny, w których dziecko uczestniczy mogą dokonywać się w dwóch rodzajach miejsc. Po pierwsze, na terenie domu lub w jego obejściu - na przykład: podwórku, ogródku, garażu, zabudowaniach gospodarczych. Po drugie, mogą zachodzić w środowisku lokalnym, w którym żyje rodzina.

Czynności wykonywane w domu to tzw. „czynności rutynowe”. Należą do nich: przygotowywanie i spożywanie posiłków, sprzątanie, pranie, zmywanie naczyń, opiekowanie się zwierzętami, pielenie ogródka itp. W przypadku małego dziecka rutynowy charakter mają: karminie, kładzenie do łóżka, kąpanie, ubieranie itp. Wykonywanie tych czynności jest doskonałą okazją do stymulowania rozwoju dziecka. $\mathrm{Na}$ przykład w trakcie kąpieli matka może kształtować ,ja cielesne dziecka”, rozwijać jego percepcję i manipulację, zachęcając do bawienia się kolorowymi pływaczkami, stymulować rozwój mowy, prowokując dziecko do wokalizowania lub nazywając

\footnotetext{
${ }^{24}$ H. Schaffer, Psychologia rozwojowa. Podstawowe pojęcia, Wyd. UJ, Kraków 2010, s. 188.

${ }^{25} \mathrm{M}$. Ainsworth, Patterns of infant - mother attachment: Antecedents and effects on development, „Bulletin of the New York Academy of Medicine” 61(1985)9, s. 785.
} 
pływające zabawki oraz uczyć reguły naprzemiennego reagowania, inicjując podczas wycierania po kąpieli zabawę w ,a ku-ku”.

Duże możliwości wspomagania rozwoju dziecka tkwią w czynnościach samoobsługowych wykonywanych we współpracy z rodzicami takich, jak: zawiązywanie butów, ubieranie się, rozbieranie, mycie rąk i twarzy, czyszczenie zębów, czesanie włosów, sprzątanie pokoju. Dziecko wykonuje wymienione czynności przy pomocy i pod kierunkiem opiekuna i stopniowo je opanowuje, dzięki czemu staje się bardziej samodzielne. Rodzice i inni członkowie rodziny powinni pozwolić dziecku na uczestniczenie w wykonywanych przez siebie czynnościach - przygotowywaniu posiłku, sprzątaniu mieszkania, prasowaniu, pieczeniu ciasta itp. Doskonałym przykładem czynności, w których dziecko może występować w rolach partnera i pomocnika jest pielęgnowanie przydomowego ogródka z kwiatami i/lub warzywami. Dziecko może uczestniczyć w takich działaniach, jak: podlewanie, pielenie chwastów, sadzenie, zbieranie owoców itp. Równie dobrą okazją do wspólnych działań są czynności związane z porządkowaniem obejścia i opieką nad zwierzętami domowymi, niektóre prace w garażu lub warsztacie wykonywane wspólnie z ojcem lub dziadkiem. Istotne jest, aby rodzice nie wyręczali dziecka, ale wspierali je w samodzielnym działaniu.

W pierwszych sześciu latach życia w codziennym funkcjonowaniu dziecka dominują zabawy. Formy zabaw zmieniają się z wiekiem dziecka i wzrostem jego sprawności w poszczególnych sferach rozwoju. Każda zabawa jest dla dziecka naturalną okazją do kształtowania i doskonalenia różnych umiejętności. Dlatego zabawy powinny stanowić integralną część codziennego życia rodziny. Dziecko należy zaopatrzyć w zabawki adekwatne do jego możliwości i pobudzające do twórczego działania. Jeśli niepełnosprawne dziecko ma rodzeństwo, pojawiają się naturalne okazje do podejmowania zabaw ze współdziałaniem. Jeśli niepełnosprawne dziecko jest jedynakiem, partnerami jego zabaw mogą być rodzice lub dziadkowie. Istotne jest, aby domownicy z chęcią włączali się w zabawy dziecka.

Codzienne życie rodziny nie ogranicza się tylko do terenu domu i jego otoczenia. Toczy się ono również w środowisku lokalnym i wszędzie tam, gdzie rodzina $\mathrm{z}$ dzieckiem przebywa ${ }^{26}$. W trakcie czynności wykonywanych poza domem pojawia się bardzo wiele okazji do wspomagania rozwoju dziecka. Można wyróżnić trzy formy pozadomowych aktywności rodziny. Pierwszą są wyjścia i wyjazdy: na zakupy do centrum handlowego lub supermarketu, na obiad do restauracji, na wizyty do przyjaciół i sąsiadów, na rodzinne uroczystości i przyjęcia, na działkę itp. Druga forma pozadomowych aktywności to wycieczki i wyjazdy na wakacje. Wiążą się one z przygotowaniami, podróżą samochodem lub środkami komunikacji publicznej, zwiedzaniem nowych, atrakcyjnych miejsc, przerwami na odpoczynek i posiłek, za-

${ }^{26}$ C. Dunst, M. Raab, M. Trivette, J. Swanson, Community-based everyday child learning opportunities, [w:] Working with families of young children with special needs, red. R. McWilliam, Gulilford Press, New York 2010, s. 66. 
kupem pamiątek, fotografowaniem lub filmowaniem zwiedzanych miejsc. Wycieczki i wyjazdy wakacyjne stwarzają możliwość poznawania nowych ludzi, miejsc, przedmiotów i zjawisk. Trzecią formą pozadomowych czynności są wyjścia i wycieczki do miejsc zapewniających rozrywkę, przede wszystkim dziecku. Takimi miejscami są: aquapark, ogród zoologiczny, oceanarium, wesołe miasteczko, skansen, wioska indiańska, ogród jurajski, gospodarstwo agroturystyczne itp.

Kolejnymi formami aktywności rodziny poza terenem domu jest udział w wydarzeniach społecznych i kulturalnych, odbywających się w środowisku lokalnym. Należą do nich: wystawy, pokazy, uroczystości z okazji różnych rocznic, zgromadzenia, festyny, festiwale, plenerowe imprezy kulturalne, jarmarki, targi itp. Władze lokalne organizują imprezy adresowane specjalnie do dzieci: konkursy, zawody, kiermasze, festiwale. Rodzice wierzący mogą uczestniczyć wraz z dzieckiem w różnych formach aktywności religijnej: niedzielnych mszach, procesjach, odpustach, modlitewnych czuwaniach, rekolekcjach, a także w akcjach i imprezach organizowanych przez parafie: jasełkach, festiwalach pieśni religijnej, wycieczkach, pielgrzymkach.

Wszystkie przedstawione wyżej formy aktywności rodziny, mające miejsce zarówno na terenie domu i w jego najbliższym otoczeniu, jak i w środowisku lokalnym, są potencjalnie źródłem bardzo licznych okazji do wchodzenia przez rodziców i innych członków rodziny w interakcje z niepełnosprawnym dzieckiem. Profesjonalni terapeuci nie dysponują tak licznymi i tak różnorodnymi możliwościami. Można powiedzieć, że sytuacje życia rodzinnego mają specyficzny, niepowtarzalny charakter, którego nie można odtworzyć, ani zaaranżować w innych okolicznościach. Specjalista nie powtórzy wielu czynności wykonywanych z dzieckiem przez rodziców i innych członków rodziny. Nie odtworzy ani nie stworzy szczególnego klimatu emocjonalnego, jaki towarzyszy codziennym interakcjom między dzieckiem i jego najbliższymi.

\subsection{Ciekawość i zainteresowania dziecka}

Oddziaływania wspomagające rozwój powinny opierać się na aktywności dziecka i wykorzystywać ją. W wieku niemowlęcym i poniemowlęcym podstawowym źródłem aktywności poznawczej dziecka jest ciekawość. „Jako proces psychiczny ciekawość jest sporadyczna, raczej krótkotrwała, przemijająca, zależna od bezpośredniego aktualnego oddziaływania bodźców"27. U dzieci w wieku od 0 do 3 lat ciekawość przejawia się w czynnościach eksploracyjnych i jest głównym mechanizmem poznawania świata i siebie. Tak może być w kolejnych latach życia u dzieci z niektórymi typami niepełnosprawności, na przykład z niepełnosprawnością intelektualną w stopniu znacznym lub niepełnosprawnością sprzężoną. Natomiast $\mathrm{u}$ innych dzieci, na przykład z niepełnosprawnością ruchową, sensoryczną lub u dzieci z grupy

\footnotetext{
${ }^{27}$ A. Gurycka, Rozwój i ksztaltowanie zainteresowań, WSiP, Warszawa 1989, s. 50-51.
} 
ryzyka, w miarę rozwoju, ciekawość zaczyna skupiać się na określonych zjawiskach i zapoczątkowuje rozwój zainteresowań.

Według Antoniny Guryckiej ,zainteresowanie jest to względnie trwała obserwowalna dążność do poznawania otaczającego świata, przybierająca postać ukierunkowanej aktywności poznawczej o określonym nasileniu"28.

Skuteczność wspomagania rozwoju dziecka w naturalnych sytuacjach życia rodzinnego zależy od tego, czy podejmowane przez dziecko czynności wynikają z jego ciekawości i zainteresowań, czy też są efektem nacisku rodziców. Stwierdzono, że gdy rodzice włączają dziecko w działania dla niego interesujące, wówczas poziom aktywności dziecka znacznie wzrasta ${ }^{29}$. Mechanizm pozytywnego wpływu zainteresowań dziecka na jego rozwój można przedstawić następująco. Osoby, przedmioty i zjawiska, którymi dziecko jest zaciekawione lub zainteresowane, wzbudzają i podtrzymują uwagę, zachęcają do zainicjowania kontaktu z nimi oraz skłaniają do uczestniczenia w czynnościach z ich udziałem. Zatem wypływające z ciekawości i zainteresowań dziecka zabawy, kontakty społeczne i czynności stanowią źródło doświadczeń korzystnych dla rozwoju. Dzięki zaangażowaniu w różne czynności dziecko ma okazję utrwalić umiejętności już posiadane, udoskonalić aktualnie nabywane oraz nabyć nowe. W konsekwencji dziecko staje się bardziej samodzielne. Ponadto działania motywowane ciekawością i zainteresowaniami służą poznawaniu własnych możliwości w zakresie wywierania wpływu na otoczenie społeczne i przedmiotowe. Dziecko ma okazję nauczyć się, że przy pomocy określonych zachowań może osiągnąć zamierzone efekty. W ten sposób kształtuje się u niego poczucie sprawstwa, które z kolei wzmacnia istniejące zainteresowania oraz sprzyja kształtowaniu się nowych.

Stwarzanie dziecku okazji do uczestniczenia w czynnościach zgodnych z jego zainteresowaniami to podstawowe zadanie wczesnego wspomagania rozwoju dziecka w środowisku rodzinnym. U małych dzieci, zarówno sprawnych, jak i niepełnosprawnych, ciekawość budzą przedmioty i zabawki posiadające niezwykłe cechy: niecodzienny kształt, kolor lub emitujące dźwięki. Rodzice mogą inicjować czynności przez dziecko nieoczekiwane, a nawet zaskakujące, oczywiście dbając, aby ich konsekwencją było zaciekawienie, a nie przestrach. Na przykład mogą zaaranżować malowanie palcami, zabawę w nadmuchiwanym basenie, przejażdżkę na kucyku lub podróż kolejką w trakcie pobytu na wycieczce itp. Ważne jest, aby stwarzali okazje do poznawania, badania i sprawdzania zawsze wtedy, kiedy dziecko taką potrzebę ujawnia. Na przykład w trakcie pobytu na działce należy pozwolić dziecku sprawdzić, jak rosną pomidory lub ogórki, jak działa zraszacz lub co kryje się pod kretowiskiem.

${ }^{28}$ Tamże, s. 33.

${ }^{29}$ C. Dunst, M. Bruder, Valued outcomes of service coordination, early intervention, and natural environments, ,Exceptional Children” 68(2002)3, s. 361-375. 
Uwzględnienie zainteresowań przy organizowaniu oddziaływań wspomagających rozwój przynosi niepełnosprawnym dzieciom wiele korzyści. Stwierdzono, że są one bardziej aktywne, mają pozytywne relacje z rówieśnikami, ujawniają mniej trudnych zachowań, mają wysoki poziom kompetencji komunikacyjnej i osiągają znaczące postępy w rozwoju psychoruchowym ${ }^{30}$. Dlatego rodzice powinni wiedzieć, czym ich dziecko się interesuje i jak wzbudzić jego ciekawość. Posiadając taką wiedzę mogą umożliwiać dziecku wykonywanie czynności, które sprawiają radość, nie są zbyt trudne i stymulują rozwój.

\subsection{Strategie postępowania rodziców $\mathrm{w}$ toku interakcji z dzieckiem}

W proponowanym modelu wczesnego wspomagania rozwoju kluczową rolę pełni jakość interakcji między rodzicami a dzieckiem. Wyróżniłem sześć cech, którymi powinny charakteryzować się interakcje wspomagające rozwój dziecka. Cechy te nie są przypisane do interakcji rodzic - dziecko na stałe. To, czy interakcja pozytywnie wpłynie na rozwój dziecka, zależy od sposobu postępowania rodzica. Dlatego rodzic powinien zadbać, aby jego interakcje $\mathrm{z}$ dzieckiem zawierały jak najwięcej cech korzystnych dla rozwoju dziecka. A zatem, jeśli w trakcie interakcji rodzic świadomie i systematycznie podejmuje określone zachowania, wówczas można powiedzieć, że posługuje się strategiami wspomagającymi rozwój. Innymi słowy, poszczególne cechy interakcji wspomagających rozwój realizują się poprzez różne strategie postępowania rodziców wobec dziecka.

Pierwszą cechą interakcji wspomagających rozwój jest okazywanie dziecku milości. „Gotowość do pokochania dziecka jest naszym ewolucyjnym wyposażeniem. To wyjaśnia emocjonalne zaangażowanie rodziców, obecne także wtedy, gdy układ ten jest niesymetryczny: dziecko nie rewanżuje się dowodami przywiązania"'31. Oto przykładowe strategie postępowania rodziców służące wyrażaniu miłości do dziecka ${ }^{32}$ :

- podejmowanie bezpośredniego, fizycznego kontaktu z dzieckiem. Rodzice starają się jak najczęściej brać dziecko na ręce, przytulać, głaskać, pieścić, kołysać. Czule dotykają dziecko w trakcie zabaw paluszkowych, zabaw w wodzie, baraszkowania oraz codziennych czynności pielęgnacyjnych ${ }^{33}$;

- reagowanie natychmiast, z czułością. Rodzice odpowiadają na wszystkie reakcje przywiązania, jakie dziecko ku nim kieruje. Traktują krzyk, płacz, kwilenie oraz

${ }^{30}$ C. Dunst, C. Trivette, D. Hamby, Research synthesis..., dz. cyt., s. 57.

${ }^{31}$ E. Pisula, Autyzm i przywiqzanie. Studia nad interakcjami dzieci z autyzmem i ich matek, GWP, Gdańsk 2003.

${ }^{32} \mathrm{Z}$ uwagi na ograniczone ramy tego opracowania, do każdej cechy interakcji podaję cztery przykładowe strategie postępowania rodziców. Pełny opis strategii można znaleźć w pracy: A. Twardowski, Wczesne wspomaganie rozwoju dzieci, dz. cyt.

${ }_{33} \mathrm{H}$. Olechnowicz, Uźródeł rozwoju dziecka. O wspomaganiu rozwoju prawidłowego i zakłóconego, Nasza Księgarnia, Warszawa 1988. 
reakcje mimiczne i ruchowe jako ważne i wskazujące, że dziecko potrzebuje ich bliskości i uwagi;

- okazywanie dziecku radości i zadowolenia. Czas spędzany z dzieckiem i wykonywane czynności są dla rodziców źródłem radości i przyjemności, a nie mozolnym obowiązkiem. Ich interakcje z dzieckiem nacechowane są ciepłem i serdecznością;

- pocieszanie i uspokajanie dziecka. Rodzice przytulają dziecko, łagodnie przemawiają i delikatnie kołyszą. Rozumieją, że dziecko jest rozdrażnione lub grymasi nie dlatego, że chce ich zdenerwować, ale dlatego, że źle się czuje.

Wrażliwe odpowiadanie na zachowania dziecka to druga cecha interakcji wspomagających rozwój. $Z$ jednej strony świadczy o świadomości rodziców, że dziecko jest odrębnym podmiotem, a $\mathrm{z}$ drugiej wyraża ich dążenie do rozpoznawania potrzeb i oczekiwań dziecka. Oto przykładowe strategie stosowane przez rodziców wrażliwie odpowiadających na zachowania dziecka:

- spoglądanie na świat oczami dziecka. Rodzice rozumieją, że dziecko spostrzega świat inaczej niż oni. Mają świadomość, że szczególnie w pierwszych latach życia dziecko odkrywa otaczającą rzeczywistość ciągle na nowo;

- wyczulenie na aktualny stan dziecka. Rodzice trafnie odczytują niewerbalne sygnały samopoczucia fizycznego i psychicznego dziecka. Na przykład wiedzą, że odchylanie się do tyłu lub odwracanie głowy w bok jest sygnałem zmęczenia;

- reagowanie na niewerbalne zachowania dziecka. Rodzice są świadomi, że przed opanowaniem mowy dziecko sygnalizuje swe potrzeby za pomocą płaczu i innych reakcji niewerbalnych. Wiedzą, że dzięki ich natychmiastowym reakcjom dziecko uczy się posługiwać tymi reakcjami w sposób intencjonalny;

- akceptowanie czynności podejmowanych przez dziecko. Rodzice niezwłocznie i pozytywnie reagują na wszystkie działania podejmowane przez dziecko z wyjątkiem takich, które są destruktywne lub szkodliwe.

Trzecią cechą interakcji wspomagających rozwój dziecka jest podzielanie tematu. Aktywność rodzica i dziecka koncentruje się wokół wspólnego elementu, który nadaje kierunek interakcji i wyznacza jej treść. Rodzic i dziecko ustalają temat za pomocą takich środków, jak: wskazywanie, kierowanie wzroku i odniesienia słowne ${ }^{34}$. Rodzice ułatwią dziecku podzielanie tematu interakcji, posługując się następującymi strategiami:

- śledzenie kierunku uwagi dziecka. Rodzice monitorują kierunek uwagi dziecka. Potrafią ustalić, jakimi przedmiotami, osobami i czynnościami jest zainteresowane. Potrafią dostrzec, kiedy dziecko przestaje interesować się jednym obiektem, a zaczyna innym;

- zachęcanie dziecka do podejmowania zabaw. Rodzice inicjują z dzieckiem krótkie zabawowe epizody w ciągu całego dnia w różnych, naturalnych sytuacjach.

${ }^{34}$ H. Schaffer, Epizody wspólnego zaangażowania..., dz. cyt., s. 153. 
Wiedzą, jakie formy aktywności zabawowej preferuje oraz jakimi zabawkami i przedmiotami najchętniej się posługuje;

- wyczekiwanie na odpowiedź dziecka. Rodzice sygnalizują dziecku, że powinno zainicjować interakcję lub odpowiedzieć na zachowanie, które do niego zaadresowali. Spojrzeniem, wyrazem twarzy, postawą ciała, gestykulacją lub słowami komunikują dziecku, że spodziewają się jego reakcji i czekają na nią;

- okazywanie dziecku radości i entuzjazmu. W kontakcie z dzieckiem rodzice okazują radość i zaangażowanie. Ich pozytywne emocje, ożywiona mimika i wyrazista gestykulacja zachęcają dziecko do zainicjowania interakcji.

Dopasowanie oddziaływań do potrzeb i możliwości dziecka to czwarta cecha interakcji wspomagających rozwój. Postępowanie rodziców jest zorientowane na strefę najbliższego rozwoju dziecka. Ich wymagania i oczekiwania nieznacznie przewyższają aktualne możliwości dziecka. Oddziaływania rodziców, zgodne z kierunkiem i rodzajem aktywności dziecka, wzmacniają nie tylko aktywność, ale również zainteresowania, które są jej źródłem. Ta cecha interakcji realizuje się poprzez następujące strategie postępowania rodziców wobec dziecka:

- uwzględnianie punktu widzenia dziecka. Rodzice rozumieją oczekiwania, zainteresowania i zdolności dziecka, źródła jego lęków, złości i radości. Potrafią ustalić na co jest szczególnie uwrażliwione, co wie i umie, co jest dla niego nagrodą, a co źródłem frustracji;

- dostosowywanie się do sposobu postępowania dziecka. W trakcie interakcji z dzieckiem rodzice naśladują zachowania dziecka. To zachęca dziecko do powtórzenia zachowania i zazwyczaj zapoczątkowuje interakcję;

- dostosowywanie się do sposobu porozumiewania się dziecka. Rodzice porozumiewają się zgodnie ze sposobem, w jaki porozumiewa się ich dziecko. Na przykład: odpowiadają gestami na gesty, wokalizacjami na wokalizacje, słowami na słowa. W relacjach z dzieckiem rodzice posługują się tzw. „mową macierzyńską”;

- dostosowywanie się do tempa aktywności dziecka. Rodzice sygnalizują dziecku gotowość do podjęcia interakcji za pomocą środków niewerbalnych, a jednocześnie nie wykonują żadnych czynności. Dzięki temu dziecko samo może zdecydować, kiedy podjąć interakcję i na jaki temat.

Wzajemność to piąta cecha interakcji wspomagających rozwój dziecka. Rodzic dostosowuje swoje zachowania do poprzedzających je zachowań dziecka, a jednocześnie zachęca dziecko do kolejnych reakcji. Dba, aby wymiana zachowań była zrównoważona, tzn. nie dominuje nad dzieckiem. Osiągnięciu wzajemności w relacjach z dzieckiem sprzyja posługiwanie się przez rodziców następującymi strategiami:

- przestrzeganie reguły zamiany ról. Aby pomóc dziecku opanować zasadę zamiany ról obowiązującą w interakcjach społecznych i podczas dialogu rodzice inicjują zabawy polegające na naprzemiennym wykonywaniu prostych czynności na przykład zabawy w ,a-kuku” lub ,bierz - oddaj”; 
- podejmowanie zabaw dźwiękonaśladowczych. Rodzic inicjuje sekwencję dźwięków emitowanych kolejno przez niego i przez dziecko. W ten sposób uczy dziecko podstawowej reguły konwersacji, jaką jest reguła naprzemiennego zabierania głosu;

- zachęcanie dziecka do wypowiadania się. Po wykonaniu czynności lub sformułowaniu wypowiedzi rodzic zachęca dziecko do udzielenia odpowiedzi: spogląda wyczekująco, uśmiecha się, podnosi brwi, rozchyla usta, gestykuluje;

- ograniczanie własnej aktywności werbalnej. Rodzic stara się mówić mniej i używać krótszych wypowiedzi. W zamian pozwala mówić dziecku. Nie niepokoi się, że w interakcji z dzieckiem pojawiają się okresy milczenia.

Szóstą cechą interakcji wspomagającej rozwój jest kierowanie zachowaniem dziecka. Rodzice unikają nadmiernego kontrolowania dziecka za pomocą poleceń, nakazów i zakazów. Stwarzają sytuacje sprzyjające podejmowaniu nowych czynności, a także zachęcają do kontynuowania już zapoczątkowanych. Wyczekują inicjatywy dziecka i pozytywnie na nią odpowiadają. Kierowaniu zachowaniem dziecka sprzyja stosowanie poniższych strategii:

- stwarzanie dziecku okazji do dokonywania wyborów. Rodzice oferują dziecku różne czynności i zabawki, aby mogło wybrać te, które są dla niego najbardziej interesujące. Szanują wybory dziecka i podejmują z nim wspólne działania;

- powtarzanie czynności sprawiających dziecku radość. Rodzice włączają się w działania dziecka naśladując je. W ten sposób mobilizują je do dalszej aktywności i doskonalenia określonych umiejętności;

- ograniczanie liczby poleceń i zakazów. Rodzice pozwalają ,aby dziecko prowadziło" i dostosowują się do linii jego aktywności. Pomagają, podpowiadają, sugerują, zachęcają i komentują czynności dziecka;

- zachęcanie dziecka do rozbudowywania działań. Rodzice nakłaniają dziecko do użycia bardziej złożonych form zachowania, jeśli zauważyli, że są one w zasięgu możliwości dziecka.

\section{Zakończenie}

Przedstawiony model nasuwa trzy wnioski dotyczące udziału rodziców w procesie wspomagania rozwoju dzieci z niepełnosprawnościami i zagrożonych niepełnosprawnością.

Po pierwsze, małe dziecko wymaga szczególnie starannej opieki, a gdy jego rozwój jest zaburzony - dodatkowej troski i pomocy. Rodzice muszą dostosować swe oddziaływania do indywidualnych właściwości dziecka oraz jego aktualnych możliwości. Muszą też zmieniać swe postępowanie w miarę, jak dziecko nabywa nowe umiejętności i uczy się nowych sposobów wchodzenia w interakcje. 
Po drugie, wspomagające interakcje prowadzą zarówno do korzystnych zmian w rozwoju dziecka, jak i umocnienia kompetencji rodziców. Pojawiające się u dziecka postępy są źródłem ich dumy i radości. U rodziców wzrasta poczucie sprawstwa i wiara we własne możliwości. W konsekwencji chętniej podejmują kolejne interakcje, które umożliwiają dziecku gromadzenie doświadczeń korzystnych dla rozwoju. Ponadto wzrasta poziom satysfakcji, jaką obie strony czerpią ze wzajemnych kontaktów.

Po trzecie, dziecko z niepełnosprawnością potrzebuje partnera akceptującego, przyjaźnie nastawionego, który chętnie wchodzi w interakcje; partnera aktywnego i wesołego, którego nie odstraszają ,trudne” zachowania dziecka i który potrafi wypracować skuteczne sposoby radzenia sobie z takimi zachowaniami. W przypadku małego dziecka wymienione warunki najlepiej mogą spełnić rodzice.

\section{Bibliografia}

Ainsworth M., Attachments across the life span, „Bulletin of the New York Academy of Medicine" 61(1985)9.

Ainsworth M., Blehar M., Waters E., Wall S., Patterns of attachment: A psychological study of the strange situation, Erlbaum, Hillsdale 1978.

Ainsworth M., Patterns of infant - mother attachment: Antecedents and effects on development, „Bulletin of the New York Academy of Medicine” 61(1985)90.

Bokus B., Nawiazywanie interakcji społecznych przez małe dziecko, Ossolineum, Wrocław 1984.

Bornstein M., Pomiędzy opiekunami a ich potomstwem: dwa rodzaje interakcji i ich konsekwencje dla rozwoju poznawczego, [w:] Dziecko wśród rówieśników i dorostych, red. A. Brzezińska, G. Lutomski, B. Smykowski, Wyd. Zysk i S-ka, Poznań 1995.

Bowlby J., Przywiazanie, Wyd. Nauk. PWN, Warszawa 2007.

Bruder M., Early childhood intervention: A promise to children and families to their future, „Exceptional Children” 76(2010)3.

Brzezińska A., Społeczna psychologia rozwoju, Wyd. Nauk. „Scholar”, Warszawa 2000.

Dąbrowska M., Wczesne wspomaganie. Wsparcie psychologiczno-pedagogiczne, Fundacja Rozwoju Regionalnego, Kraków 2009.

Dunst C., Bruder M., Valued outcomes of service coordination, early intervention, and natural environments, „Exceptional Children”, 68(2002)3

Dunst C., Early intervention for infants and toddlers with developmental disabilities, [w:] Handbook of developmental disabilities, red. S. Odom, R. Horner, M. Snell, J. Blacher, Guilford Press, New York 2007.

Dunst C., Raab M., Trivette M., Swanson J., Community-based everyday child learning opportunities, [w:] Working with families of young children with special needs, red. R. McWilliam, Gulilford Press, New York 2010.

Gruszczyk-Kolczyńska E., Zielińska E., Wspomaganie rozwoju umysłowego trzylatków $i$ dzieci starszych wolniej rozwijajacych sie, WSiP, Warszawa 2000.

Gurycka A., Rozwój i kształtowanie zainteresowań, WSiP, Warszawa 1989. 
Mahoney G., MacDonald J., Autism and developmental delays in young children. The responsive teaching curriculum for parents and professionals, PRO-ED, Austin 2007.

McBridge S., Peterson C., Home-based early intervention with families of children with disabilities: Who is doing what?, „Topics in Early Childhood Special Education” 17(1997)2.

McWilliam R., Routine-based early intervention: supporting young children and their families, Brookes Publishing, Baltimore 2010.

Moore T., Larkin H., "More than my child's disability..." A comprehensive review of family-centered practices and family experiences of early childhood intervention service, Scope, Melbourne 2006.

Olechnowicz H., U źródet rozwoju dziecka. O wspomaganiu rozwoju prawidłowego i zaktóconego, Nasza Księgarnia, Warszawa 1988.

Pisula E., Autyzm i przywiazanie. Studia nad interakcjami dzieci z autyzmem i ich matek, GWP, Gdańsk 2003.

Schaffer H., Epizody wspólnego zaangażowania jako kontekst rozwoju poznawczego, [w:] Dziecko w świecie ludzi i przedmiotów, red. A. Brzezińska, G. Lutomski, Wyd. Zysk i S-ka, Poznań 1994.

Schaffer H., Początki uspołecznienia dziecka, PWN, Warszawa 1981.

Schaffer H., Psychologia rozwojowa. Podstawowe pojęcia, Wyd. UJ, Kraków 2010.

Twardowski A., Wczesne wspomaganie rozwoju dzieci z niepetnosprawnościami w środowisku rodzinnym, Wydawnictwo Naukowe UAM, Poznań 2012.

Wrona S., Wczesna interwencja $i$ wczesne wspomaganie procesem wspierajacym rozwój matego dziecka, [w:] Wsparcie instytucjonalne osób niepetnosprawnych w Polsce i Republice Czeskiej, red. I. Fajfer-Kruczek, S. Wrona, Wyd. „ARKA”, Cieszyn 2010.

Zimmerman M., Psychological empowerment: Issues and illustrations, „American Journal of Community Psychology" 23(1995)5.

\title{
NEW CONCEPT OF EARLY SUPPORT FOR CHILDREN WITH DISABILITIES
}

\begin{abstract}
The subject of this article is a modern view on early support for children with disabilities. In the past twenty years the traditional paradigm of early support, which is professional-centered, had been replaced with a more advanced, family-centered one. The essential difference between those two is the idea of working with children with special needs. In the second paradigm, direct interactions between the child and professionals turned into cooperation with families, as well as building partner relations with their members, especially parents.

The author presents his own model of early support of child's development focused on interactions between parents and the child with its four main elements: (1) characteristics of interactions influencing child's development, (2) daily activities of the family, (3) curiosity and interest of the child, and (4) strategies used by parents interacting with the child.
\end{abstract}

Key words: early support, children with disabilities, development, family. 
Andrzej Twardowski - prof. dr hab., kierownik Zakładu Psychopatologii Dziecka na Wydziale Studiów Edukacyjnych Uniwersytetu im. Adama Mickiewicza w Poznaniu. Autor następujących prac naukowych: Kształcenie dialogowej kompetencji komunikacyjnej u uczniów niepetnosprawnych intelektualnie, Wydawnictwo Instytutu Pedagogiczno-Artystycznego UAM, Kalisz-Poznań 2002, Wczesne wspomaganie rozwoju dzieci z niepełnosprawnościami w środowisku rodzinnym, Wydawnictwo Naukowe UAM, Poznań 2012 (wydanie drugie 2014), Wspomaganie rozwoju dzieci ze złożonymi zespołami zaburzeń, Wyd. Nauk. PTP, Poznań 2005 (redakcja i współautorstwo), Wspomaganie dzieci z genetycznie uwarunkowanymi wadami rozwoju $i$ ich rodzin, Wyd. Nauk. PTP, Poznań 2006 (redakcja i współautorstwo), Wspomaganie rozwoju dzieci z rzadkimi zespołami chromosomowymi, Wyd. Nauk. PTP, Poznań 2008 (redakcja i współautorstwo), Wspomaganie rozwoju dzieci z rzadkimi zespołami genetycznymi, Wyd. Nauk. PTP, Poznań 2009 (redakcja i współautorstwo).

Adres e-mail: ajt@amu.edu.pl 